www.jmscr.igmpublication.org Impact Factor 5.244

Index Copernicus Value: 5.88 ISSN (e)-2347-176x ISSN (p) 2455-0450 crossref DOI: _http://dx.doi.org/10.18535/jmscr/v4i6.45

\title{
Special Case Report On Katigata vata (Lumbar Spondylosis)
}

\author{
Authors \\ Dr Sanjay S. Patil ${ }^{1}$, Dr Sandip Shahajirao Patil ${ }^{2}$ \\ ${ }^{1}$ M.D. Kayachikitsa, HOD \& Reader Dept. of Kayachikitsa, LRP Ayurved College, Islampur \\ Email-drpsanjaymd@gmail.com, Mob.-9960992124 \\ ${ }^{2}$ M.D. Kayachikitsa, Reader Dept. of Rognidan, LRP Ayurved College, Islampur \\ Mob.- 9823531537
}

\begin{abstract}
A male patient of age 75 yrs old brought by relatives to LRP ayurvedic Hospital with having complaints of Katishoola radiating to ubhaya Pada. Asane Gamane kashthata (not able to walk) and unable to stand for long time. Since 6 months. He has taken allopathic medication temporary relief got only in pain.

He has given ayurvedic and Panchkarma treatment. In this case we have got very good results by above mentioned treatment.
\end{abstract}

Keywords: Lumbar spondylosis, Ayurvedic treatment.

\section{Introduction}

A male patient of age 75 yrs old brought by relatives to LRP ayurvedic Hospital with having complaints of

Katishoola radiating to ubhaya Pada. Asane Gamane kashthata (not able to walk)and unable to stand for long time. Since 6 months.

He has taken allopathic medication temporary relief got only in pain. Known case of Diabetis taking medicine. He has advised to do operation. But came to our hospital for Ayurvedic treatment. Patient was admitted in Kayachikitsa ward.

\section{General examination}

Pulse: $80 /$ min. Temp: $98.8^{0}$ F B. P. 160/90.

R. R. 20/ min. Kshudha: Prakrut Nidra: Alpa

Mala: Samyak Mutra: Samyak
Dosha - Vatapradhana Kapha. Dushya: Mamsa, Sira, Snayu. Mala: Purisha

Srotas: Rasa, Mamsa, Purisha and Manovaha.

SLR: Positive for the both legs at $30^{\circ}$

Diagnosis: Ghudhrasi.

\section{Investigation}

MRI plain Lumbar Spine.

1. Changes of lumbar spondolosis.

2. Circumferential post. Buldge at L2 - L3, L3-L4, L4 - L5 level intending the ant. Thecal sac encroaching over, the inferior aspect of bilateral neuron foramina and imparing over contained nerve root.

\section{Treatment given}

Sthanik snehan with Kottamchukadi taila.

Bashpa sweda with Dashmoola kwath. 
Nasya with Panchendriya tail 2 drops in each nostril in the morning.

Matrabasti basti with Tikata ksheer basti $250 \mathrm{ml}$ for 8 days.

In between matrabasti on $3^{\text {rd }}, 5^{\text {th }}$ and $7^{\text {th }}$ day Niruha basti given Dashmoola Triphala Kwath $450 \mathrm{ml}$.

Katipicchu with Kottam chukadi taila

Shirodhara with Brahmhi taila at evening.

\section{Oral Treatment given}

1. T. Bruhat vata chintamani 1 OD with Madhu.

2. Cap Palsyneuron 1 TDS with Jal.

3. Dashmoola kashaya $20 \mathrm{ml} \mathrm{BD}$ with Jal.

4. T. Sarpgandha vati $250 \mathrm{mg} \mathrm{Bd}$ with Jal.

For 10 days.

After 10 days of Treatment -Patient is able to walk few steps slowly. Katishoola is relieved very well.

\section{Advice}

Continue oral medication till next panchakarma setting.

\section{Mode of Action}

Tikta ksheer basti in indicated asthi majjavaha vyadhi.

Asthivaha strotas chikitsa contains Tikta rasatmak kshir basti with ghrut or other sneha is indicated. Tikta Ksheer basti contains kantakari, nimb, patol, guduchi, vasa all of they are tikta gunatmak \& with kshirpak it also acts vatashaman karma. Tikta guna acts as alpa pachan and dhatvagni vruddhi so for that asthi dhatvagni vrudhi done in proper manner \& good forms of asthi dhatu develops \& asthi kshay stops.

\section{Conclusion}

In this case we have got very good results by above mentioned treatment.

\section{References}

1. Acharya Vidyadhar Shukla, Prof. Ravi Dutt Tripathi, "Charak Samhita", Vaidya Manorama Hindi Commentary, Edition 2002, Sutra sthan 28.

2. Dr. Brahmanand Tripathi, "Nirmala" Hindi Commentary, "Astanga Hrudayam," Edition 2007, sutra 13/1.

3. Acharya Vidyadhar Shukla, Prof. Ravi Dutt Tripathi, "Charak Samhita", Vaidya Manorama Hindi Commentary, Edition 2002, Chikitsa sthan 28.

4. Acharya Vidyadhar Shukla, Prof. Ravi Dutt Tripathi, "Charak Samhita", Vaidya Manorama Hindi Commentary, Edition 2002, Chikitsa Viman 5. 